\title{
Successful Business Strategies for Insurers Entering and Growing in Emerging Markets
}

\author{
Thomas R. Berry-Stölzle ${ }^{\mathrm{a}}$, Robert E. Hoyt ${ }^{\mathrm{a}}$ and Sabine Wende ${ }^{\mathrm{b}}$ \\ ${ }^{a}$ Terry College of Business, University of Georgia, 206 Brooks Hall, Athens, GA, 30602, US. \\ E-mails: trbs@terry.uga.edu; rhoyt@terry.uga.edu \\ ${ }^{\mathrm{b}}$ Department of Risk Management and Insurance, University of Cologne, Albertus-Magnus-Platz, \\ 50923 Cologne, Germany. \\ E-mail: sabine.wende@uni-koeln.de
}

Entering new markets and growing in existing ones is an area of major interest within the insurance industry across the globe. Insurance market growth rates in emerging markets are far in excess of those available in most developed countries. While these growth rates have attracted new and existing firms to these markets, corporate managers face a number of important strategic decisions as they consider establishing or expanding operations in emerging markets. This study evaluates the impact of several strategies on insurer performance in emerging markets. The main findings suggest that overall, successful business strategies for insurers entering or growing in emerging markets involve a high growth rate, increased size and more emphasis on life insurance. When performance is adjusted for risk, lower financial leverage and mutual organisational form are associated with better performance. However, differences in successful business strategies arise across countries when we control for country-level economic and market characteristics.

The Geneva Papers (2010) 35, 110-128. doi:10.1057/gpp.2009.35

Keywords: emerging markets; insurance company operations; growth; diversification

\section{Introduction}

Entering new markets and growing in existing ones is an area of major interest within the insurance industry across the globe. Insurance market growth rates in emerging markets are far in excess of those available in most developed countries. While these growth rates have attracted new and existing firms to these markets, corporate managers face a number of important strategic decisions as they consider establishing or expanding operations in emerging markets. Decisions such as choosing the degree to which they will diversify their firm's product mix, determining how heavily to focus on life versus non-life insurance, setting targets for how quickly to grow the business, establishing levels for the financial leverage of the firm and determining the optimal size are some of the important ones that must be reached. Although the opportunities available to insurers in emerging markets seem very attractive, little research has been done to identify and assess successful business strategies for insurers entering or expanding in emerging markets. In fact, we are not aware of any academic study that has utilized performance data from individual insurers operating in a wide range of emerging markets to identify successful business strategies. The goal of this study is to identify and assess successful business strategies for insurers entering or expanding in these emerging markets. 
Utilizing data on insurers operating in 50 countries, we are able to measure the value of some critical business strategies in emerging markets. It is important to note that it is very likely that the results that we find for emerging markets may differ significantly from the results for developed countries. Taking diversification as one example, the recent consensus in the literature for firms operating in developed countries is that a focus strategy dominates diversification. However, it is an open question whether that same result will hold for emerging markets. In fact, the trade-off between the economies of scope associated with diversification benefits and the control of agency costs that favours focus may well balance out differently in emerging markets. Although our primary focus is on identifying successful business strategies in emerging markets, contrasts with the answers we see in developed countries would not be surprising. ${ }^{1}$

The study is organised as follows. In the next section, we describe our methodology and related literature. Second, we discuss the data analysis. Third, we then review the sample and the data that we use in the study. Fourth, we provide summary data by country for the insurers in our sample. Fifth, we present empirical results from four different analyses that evaluate the five strategic decisions that we consider in this study. Finally, we offer conclusions.

\section{Methodology and related literature}

Using data on 456 insurance companies across 50 developing countries over the period 2004 through 2007, we examine the impact of various business strategies on the performance of insurance groups. As mentioned above, our focus is on the following strategic decisions facing management of insurers in emerging markets: (1) choosing

\footnotetext{
${ }^{1}$ The value of diversification and focus strategies has been the topic of debate in both the academic literature and the trade press for many years. Based on various samples and time periods, prior studies find contradictory results on the value implications of these strategies. The diversification and focus literature has found evidence of value-enhancing motivations for both strategies. During the 1960's and 1970's, research suggested that companies realized firm-value benefits from diversification strategies (e.g. Hubbard and Palia, 1999; and Matsusaka, 1993). However, in more recent years, research indicates that firms utilizing focus strategies achieved enhanced value (e.g., Hoyt and Trieschmann, 1991; Lang and Stulz, 1994; Tombs and Hoyt, 1994; Berger and Ofek, 1995; Comment and Jarrell, 1995; John and Ofek, 1995; Servaes, 1996; Denis et al., 1997; Cummins et al., 2003; Laeven and Levine, 2007; and Liebenberg and Sommer, 2008). The decision to diversify or focus is balanced by a series of offsetting costs and benefits. Traditional motivations for diversification center around the benefits of smoother earnings, increased internal capital markets, and capturing new expertise in changing environments (e.g. Lawellen, 1971; Teece, 1980; Myers and Majluf, 1984; and Markides, 1992). The benefits of diversification are similar to the benefits of corporate hedging discussed by several authors (e.g., Stulz, 1996; Colquitt and Hoyt, 1997; Leland, 1998; and Graham and Rogers, 2002). In both cases, firms seek to increase value through a reduction in earnings volatility. Firms electing diversification or focus strategies must examine these costs and benefits and select the appropriate strategy. The important decision of diversification within a single industry has only been addressed more recently and to a much lesser extent (e.g., Laeven and Levine, 2007; and Liebenberg and Sommer, 2008). Few studies have looked at firms across different countries and, to our knowledge, no study has considered the trade-offs for this important stategic decision in less-developed countries. This gap in the literature is all the more important given the rapid growth in insurance operations in emerging markets.
} 
the degree to which they will diversify their firm's product mix, (2) determining how heavily to focus on life versus non-life insurance, (3) setting targets for how quickly to grow the business, (4) establishing levels for the financial leverage of the firm; and (5) determining the optimal size. These are some of the important strategic decisions that must be reached.

Although few studies have focused on firm-level data across multiple countries, a number of prior papers have studied various aspects of insurance internationally. Browne and Kim, ${ }^{2}$ Browne et al., ${ }^{3}$ and Hussels et $a .^{4}$ have studied factors affecting insurance demand across countries. Other authors have focused on assessing the relation between economic growth and insurance markets in various countries. ${ }^{5} \mathrm{Ma}$ and Pope $^{6}$ look at performance and market structure at the country level.

\section{Data analysis}

We use return on equity (ROE) and risk-adjusted return on equity (RAROE) as our two measures of insurer performance. First, we provide comprehensive summary data by country for returns, premium growth, insurer size and market penetration. Second, we evaluate differences between high-performing and low-performing insurers in our sample, focusing specifically on firm size, degree of financial leverage, business mix (life versus non-life), pace of growth and group affiliation. Third, we evaluate specific strategies that contribute to performance overall, again focusing on diversification, growth rates, business mix, size and financial leverage. Fourth, we consider the implications of country-specific effects on the importance of three different strategies: diversification, growth and business mix. Following Arena, ${ }^{7}$ the country-specific characteristics that we use to capture a country's economic development or market characteristics are: GDP per capita, insurance market concentration, insurance penetration, credit to private sector, stock market turnover (total shares traded to average market capitalization), trade openness, and a corruption index.

\section{Sample and data}

We use company-level data from A. M. Best's Statement File Global for the years 2004 through 2007. Our initial sample consists of all listed insurance companies operating in developing countries. The classification of developing countries used in this study is the one provided by the International Monetary Fund. First, we eliminate all companies classified as reinsurers or pure holding companies. We then aggregate affiliated insurers operating in one country, controlling for potential double counting

\footnotetext{
${ }^{2}$ Browne and Kim (1993).

${ }^{3}$ Browne et al. (2000).

${ }^{4}$ Hussels et al. (2005).

${ }^{5}$ See Outreville (1990, 1996), Ward and Zurbruegg (2000), Webb et al. (2002) and Arena (2008).

${ }^{6} \mathrm{Ma}$ and Pope (2008).

${ }^{7}$ Arena (2008).
} 
of intra-group shareholding. Such an aggregation is appropriate as strategic decisions are usually made or directed on the group level and not by individual subsidiaries. ${ }^{8} \mathrm{We}$ exclude insurers with missing data on basic accounting variables, including total assets, policy-holder surplus, profit before taxes, life insurance premium earned and non-life insurance premiums earned. As we use historic risk measures, which require five years of data, we exclude firm-year observation for which the preceding five years of data are not available. Finally, we exclude extreme outliers. Our first outlier screen is to eliminate firm-year observations with reported life (non-life) insurance premiums in excess of the overall premium volume of the corresponding country's life (non-life) insurance market. ${ }^{9}$ Next, we follow Laeven and Levine ${ }^{10}$ and eliminate observations where the variables are more than four standard deviations from the sample mean. Finally, we eliminate observations if the ROE has a value above one or below minus one. ${ }^{11}$ The resulting sample consists of 1,588 firm-year observations with a maximum of 456 unique insurers in 2004. The sample includes insurers from 50 different countries over the period 2004 through $2007 . .^{12}$

In our analysis, we use additional variables that might influence insurer performance, including GDP per capita, inflation, market concentration, insurance penetration, credit to the private sector, stock market turnover, trade openness, and a corruption index. Premium data on the country level, the corruption index, and data on other country characteristics are obtained from Swiss Re's Sigma publications, Transparency International's website, and the World Bank's World Development Indicators database, respectively. Some of these variables are not available for all 50 countries and all four years in our sample. Thus, the number of observations used varies slightly across our estimated models.

Table 1 contains summary statistics of selected variables for the overall sample, as well as for all 50 countries in the sample separately. The two performance measures used in this study are the ROE, which is calculated as profit before taxes divided by policy-holder surplus, and the RAROE, which is the ROE divided by the standard deviation of the ROE over the past five years. Both performance measures vary substantially across insurers in our sample. The median ROE ranges from -6.4 per cent for insurers operating in Uruguay to 48.19 per cent for insurers operating in Pakistan, and the RAROE ranges from -0.32 for insurers operating in Romania to values over 5.9 for insurers operating in Egypt, Jordan, Kuwait and Bosnia and Herzegovina. The sample median for ROE is 13.49 per cent and the sample median for

\footnotetext{
${ }^{8}$ Berger et al. (2000).

${ }^{9}$ Country aggregates of life insurance premiums and non-life insurance premiums are obtained from Swiss Re's Sigma publications.

${ }^{10}$ Laeven and Levine (2007).

${ }^{11}$ Berger and Ofek (1995).

${ }^{12}$ The 50 countries included in our sample are: Antigua and Barbuda, Argentina, Bahamas, Bahrain, Barbados, Bolivia, Bosnia and Herzegovina, Brazil, Bulgaria, Chile, Croatia, Czech Republic, Dominican Republic, Ecuador, Egypt, El Salvador, Estonia, Ghana, Hungary, India, Indonesia, Jamaica, Jordan, Kazakhstan, Kuwait, Latvia, Lithuania, Malaysia, Mexico, Morocco, Nigeria, Oman, Pakistan, Panama, Peru, Philippines, Poland, Qatar, Romania, Russian Federation, Saudi Arabia, Slovakia, South Africa, Tanzania, Thailand, Trinidad and Tobago, Tunisia, Turkey, United Arab Emirates, and Uruguay.
} 


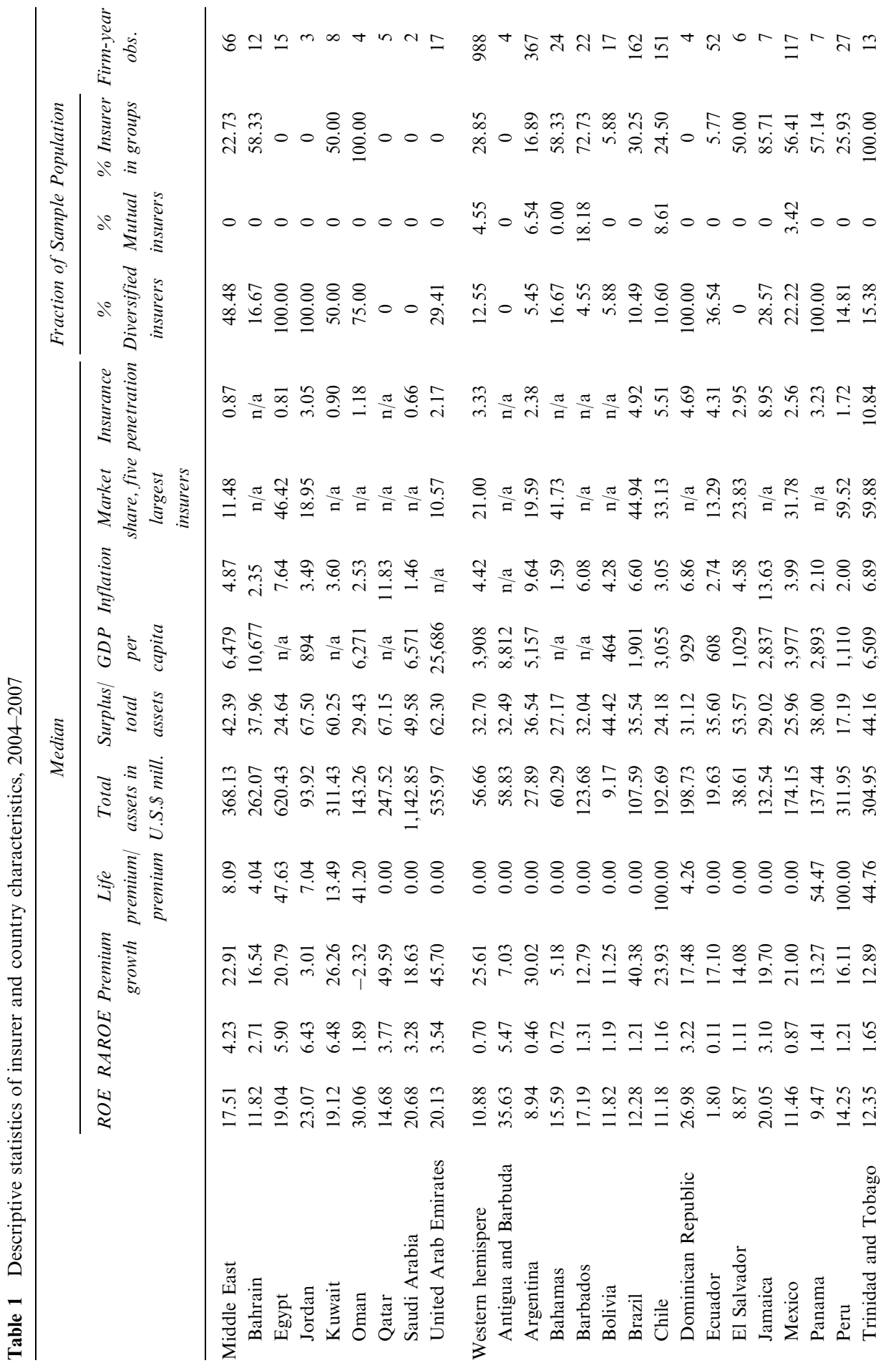




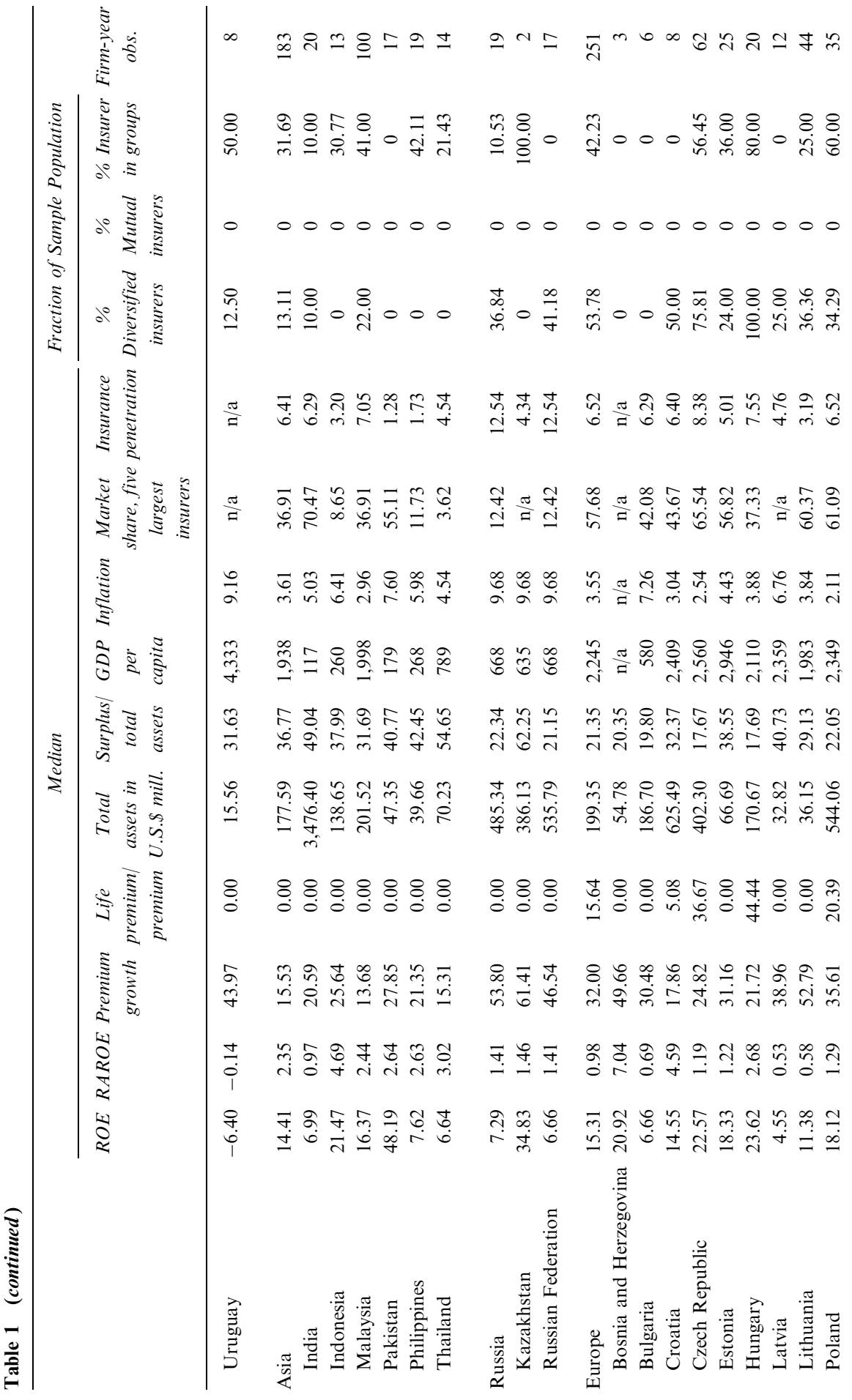




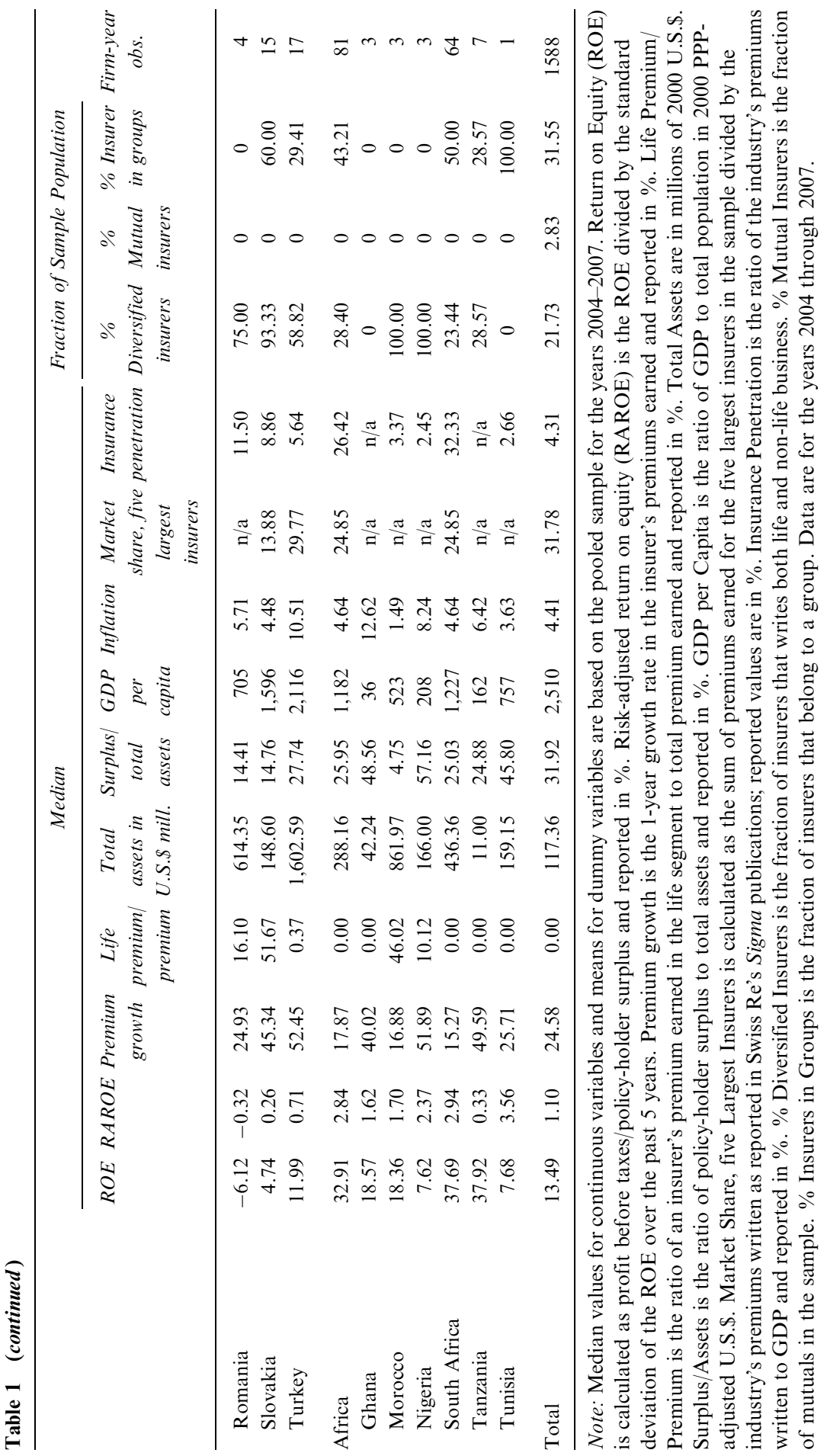


the one year premium growth variable is 24.58 per cent, documenting fast growth and solid earnings for insurers operating in emerging markets over the period 2004-2007. However, the median size of an insurance company in a developing country is still relatively small (U.S.\$ 117 million in total assets), and the median insurance penetration defined as total life and non-life premiums as a percent of a country's GDP is only 4.31 per cent, which is well below the 2007 world average of 7.5 per cent, leaving room for substantial future growth of the insurance industry in many of these emerging markets. ${ }^{13}$

\section{Differences between high-performance and low-performance insurers}

We first highlight some differences between high-performance and low-performance insurers in our sample. Table 2 presents means and medians of selected variables for the top 10 per cent of insurers, the top 20 per cent of insurers, and the bottom 80 per cent of insurers. We classify insurers for each of the four years in our sample separately. Hence, a specific company could be classified as top 20 per cent in one year and as bottom 80 per cent in the other three years. The classification in Panel A of Table 2 is based on insurers' ROE and the classification in Panel B is based on insurers' RAROE.

Based on $t$-tests for differences in means, non-parametric tests for differences in medians, and $\chi^{2}$ tests, the top 10 per cent ROE insurers are larger; have a lower surplus to assets ratio; have a higher percentage of life insurance business; are growing faster; and belong to a group. Top 10 per cent RAROE insurers are larger; have a higher percentage of life insurance business; are diversified (write both life and non-life business); and are growing faster. Fast Growth Dummy is a dummy variable coded as 1 if an insurer is above the 66th percentile of the distribution of premium growth in a given year, and 0 otherwise.

\section{The impact of insurers' business strategies on their performance}

To examine the impact of insurers' business strategy choices on their performance, we regress ROE and RAROE on variables describing insurers' strategies and additional variables controlling for differences in insurer and country characteristics. We specifically examine whether a diversification strategy results in better performance than a focus strategy by including a Diversification Dummy. This variable is coded as 1 for insurers operating in both the life and non-life market segment, and 0 otherwise. We also examine whether a fast growth strategy results in superior performance by including the Fast Growth Dummy and the Low Growth Dummy in our model. The Fast Growth Dummy is coded as 0 if an insurer is above the $66^{\text {th }}$ percentile of the distribution of premium growth in a given year, and 0 otherwise, and the Low Growth Dummy is coded as 1 if an insurer is below the $33^{\text {rd }}$ percentile of the distribution, and 0 otherwise. The omitted category is medium growth. We also include the Life Premium/

\footnotetext{
${ }^{13}$ Premium data on the country level is obtained from Swiss Re's Sigma publications.
} 
Table 2 Univariate comparison between high-performance and low-performance insurers

\begin{tabular}{|c|c|c|c|c|c|c|}
\hline & \multicolumn{2}{|c|}{ Top $10 \%$ insurers } & \multicolumn{2}{|c|}{ Top $20 \%$ insurers } & \multicolumn{2}{|c|}{ Bottom $80 \%$ insurers } \\
\hline & Mean & Median & Mean & Median & Mean & Median \\
\hline \multicolumn{7}{|l|}{ Panel A: ROE } \\
\hline Total assets & $2,029.526$ & $211.773 * * *$ & $1,651.358$ & $105.997 * * *$ & $1,002.525$ & 164.905 \\
\hline ln (Total assets) & $12.297 * * *$ & $12.263^{* * *}$ & $12.082 * * *$ & $11.571^{* * *}$ & 11.471 & 12.013 \\
\hline Surplus/assets & $0.277 * * *$ & $0.257 * * *$ & $0.294 * * *$ & $0.336^{* * *}$ & 0.363 & 0.270 \\
\hline Life premium/premium & $0.512 * * *$ & $0.392 * * *$ & $0.440 * * *$ & $0.000 * * *$ & 0.318 & 0.246 \\
\hline Diversification dummy & 0.217 & & $0.253^{*}$ & & 0.208 & \\
\hline Fast growth dummy & $0.429 * *$ & & $0.409 * *$ & & 0.336 & \\
\hline Mutual dummy & 0.019 & & $0.013^{*}$ & & 0.323 & \\
\hline Group dummy & $0.404 * *$ & & $0.366^{* *}$ & & 0.303 & \\
\hline No. of observations & 161 & & 320 & & 1268 & \\
\hline
\end{tabular}

Countries with more top $20 \%$ insurers than sample average: Antigua and Barbuda, Czech Republic, Hungary, Kazakhstan, Oman, Pakistan, South Africa, Tanzania.

Panel B: RAROE

Total assets

$\ln$ (Total assets)

Surplus/assets

Life premium/premium

Diversification dummy

Fast growth dummy

Mutual dummy

Group dummy

No. of observations

$\begin{array}{cc}2,789.423^{* * * *} & 213.917^{* * *} \\ 12.561^{* * *} & 12.273^{* * *} \\ 0.332 & 0.307 \\ 0.368 & 0.111^{* *} \\ 0.342^{* * *} & \\ 0.416^{*} & \\ 0.043 & \\ 0.348 & \end{array}$

161

\section{$2,246.623^{* * *}$}

$12.460 * * *$

0.339

0.315

$0.297 * * *$

$0.391 *$

$0.047 * *$

$0.391 * * *$

320

$\begin{array}{cr}90.647 * * * & 852.300 \\ 11.415^{* * *} & 11.376 \\ 0.322 & 0.352 \\ 0.000 & 0.349 \\ & 0.197 \\ & 0.341 \\ & 0.024 \\ & 0.297\end{array}$

1268
203.386

12.223

0.317

0.000

197

0.024

297

Countries with more top $20 \%$ insurers than sample average: Antigua and Barbuda, Bahrain, Barbados, Bosnia and Herzegovina, Croatia, Egypt, Hungary, Indonesia, Jamaica, Jordan, Kuwait, Malaysia, Philippines, Poland, Qatar, South Africa, Tanzania, Thailand, Trinidad and Tobago, Tunisia, United Arab Emirates.

Note: Statistical significance of difference in means between top $10 \%$ insurers and bottom $90 \%$ insurers and between top $20 \%$ insurers and bottom $80 \%$ insurers is based on a $t$-test. Statistical significance of difference in medians is based on a non-parametric median test. For the dummy variables, the reported significance is based on a $\chi^{2}$-test. The listed countries have significantly more top $20 \%$ insurers than the sample average based on a $\chi^{2}$-test and a 10 per cent significance level. ***,**, and $*$ denotes statistical significance at the 1 , 5, and 10 per cent level, respectively. Data are for the years 2004 through 2007.

Premium variable in our model to analyse whether the life insurance market segment or the non-life insurance market segment is more profitable in developing countries. Life Premium/Premium is the ratio of an insurer's premium earned in the life insurance segment to its total premium earned. All regression specifications include country and year dummies (not reported in the table); standard errors are adjusted for clustering at the company level.

The results of this portion of the analysis are presented in Table 3 . The results suggest that: diversification does not matter; fast growth is good; life insurance is more 
Thomas R. Berry-Stölzle et al

Table 3 Regression of insurer performance on business strategy variables and controls

\begin{tabular}{|c|c|c|c|c|c|c|}
\hline & & $R O E$ & & & $R A R O E$ & \\
\hline & (1) & (2) & (3) & (4) & (5) & (6) \\
\hline Diversification dummy & -0.005 & & -0.006 & 0.539 & & 0.528 \\
\hline & $(-0.23)$ & & $(-0.30)$ & $(1.39)$ & & $(1.37)$ \\
\hline Fast growth dummy & & $0.038 * * *$ & $0.038 * * *$ & & $0.408 * *$ & $0.406^{* *}$ \\
\hline & & $(3.18)$ & (3.18) & & $(2.15)$ & $(2.14)$ \\
\hline Slow growth dummy & & -0.014 & -0.014 & & -0.055 & -0.048 \\
\hline & & $(-0.96)$ & $(-0.96)$ & & $(-0.31)$ & $(-0.28)$ \\
\hline Life premium/premium & $0.074 * * *$ & $0.074 * * *$ & $0.075^{* * *}$ & $0.485^{* *}$ & $0.525 * *$ & $0.484 * *$ \\
\hline & $(3.80)$ & $(3.87)$ & $(3.84)$ & $(2.30)$ & $(2.36)$ & $(2.29)$ \\
\hline ln (Total assets) & $0.023 * * *$ & $0.023^{* * *}$ & $0.023 * * *$ & $0.295^{* * *}$ & $0.331 * * *$ & $0.304 * * *$ \\
\hline & $(3.00)$ & $(3.14)$ & $(3.12)$ & $(5.05)$ & $(5.18)$ & $(5.17)$ \\
\hline Surplus/assets & 0.072 & 0.079 & 0.079 & $1.438 * * *$ & $1.519 * * *$ & $1.503 * * *$ \\
\hline & (1.19) & $(1.30)$ & $(1.31)$ & $(2.94)$ & $(3.06)$ & $(3.07)$ \\
\hline Growth in assets & -0.003 & -0.003 & -0.003 & -0.027 & -0.027 & -0.027 \\
\hline & $(-0.83)$ & $(-0.85)$ & $(-0.85)$ & $(-1.38)$ & $(-1.32)$ & $(-1.38)$ \\
\hline Growth in income & 0.000 & 0.000 & 0.000 & 0.000 & 0.000 & 0.000 \\
\hline & $(0.97)$ & $(1.40)$ & (1.37) & $(0.27)$ & $(0.34)$ & $(0.52)$ \\
\hline Mutual dummy & -0.015 & -0.011 & -0.010 & $1.966^{* *}$ & $2.069 * *$ & $2.008 * *$ \\
\hline & $(-0.17)$ & $(-0.13)$ & $(-0.12)$ & $(2.02)$ & $(2.01)$ & $(2.06)$ \\
\hline Group dummy & -0.000 & -0.000 & 0.001 & 0.022 & 0.147 & 0.032 \\
\hline & $(-0.00)$ & $(-0.01)$ & $(0.05)$ & $(0.09)$ & $(0.65)$ & $(0.13)$ \\
\hline GDP per capita growth & $0.763 *$ & $0.747 *$ & $0.752 *$ & 10.163 & 10.472 & 10.050 \\
\hline & $(1.71)$ & $(1.65)$ & $(1.66)$ & $(1.35)$ & $(1.40)$ & $(1.34)$ \\
\hline Inflation & 0.004 & 0.004 & 0.004 & -0.010 & -0.005 & -0.010 \\
\hline & $(1.62)$ & $(1.58)$ & $(1.60)$ & $(-0.30)$ & $(-0.16)$ & $(-0.30)$ \\
\hline$R^{2}$ & 0.190 & 0.200 & 0.200 & 0.244 & 0.246 & 0.248 \\
\hline No. of observations & 1501 & 1501 & 1501 & 1501 & 1501 & 1501 \\
\hline
\end{tabular}

Note: The regressions include country and year dummies (not reported here). Standard errors are adjusted for clustering at the company level. Data are for the years 2004 through 2007.***,**, and * denotes statistical significance at the 1,5 , and 10 per cent level, respectively.

profitable than non-life; and size is good. A high surplus to asset ratio is only important for RAROE, but not for ROE. This latter result reflects the importance of considering risk when relating financial leverage to performance.

\section{Mediating effects of country characteristics}

In order to assess whether the relationship between insurers' strategic choices (e. g., diversification, business mix, size, degree of financial leverage and pace of growth) and their performance depends on the characteristics of the country they operate in, interaction terms are included in the performance regressions. Following a methodology similar to that used in Arena, ${ }^{7}$ the Diversification Dummy variable, the Fast Growth and Low Growth Dummy variables, and the Life Premium/Premium variable are interacted with dummy variables capturing different levels of economic development across countries (below the $33^{\text {rd }}$ percentile value of the distribution across our sample in a given year, between the 33rd and 66th value of the distribution, 
120

and above the 66th percentile value of the distribution). Measures capturing a country's economic development or other country-specific characteristics in this study are the following: (1) GDP per Capita; (2) Market Concentration, which is calculated as the sum of premiums earned for the five largest insurers in the sample, divided by the industry's premiums written as reported in Swiss Re's Sigma publications; (3) Insurance Penetration; (4) Credit to Private Sector, which is the amount of credit banks give to the private sector as a per cent of GDP; (5) Stock Market Turnover, which is the ratio of total shares traded to the average market capitalization; (6) Trade Openness, which is calculated as the natural logarithm of the ratio of exports and imports to GDP; and (7) Transparency International's Corruption Perceptions Index. ${ }^{14}$ All regression specification include country and year dummies (not reported); standard errors are adjusted for clustering at the company level. These results are presented in Table 4.

The results in Table 4 are as follows:

Diversification: It does not matter for ROE. Diversification seems to be positively related to RAROE in certain countries: in high corruption countries (low levels of corruption perceptions index), in countries with high trade barriers (low trade openness), and in countries with low market concentration (strong competition). In countries with low trade barriers (high trade openness) diversification seems to hurt.

Growth: This has a positive effect in countries with high GDP per Capita, low insurance penetration, and low trade openness. The interaction effects with market concentration, corruption, credit to private sector and stock market turnover are unclear with respect to the Fast Growth Dummy. Slow Growth seems to hurt ROE in high trade openness, low corruption (high corruption index) environments, and other factors are not significant or the effect is unclear.

Life Business vs. non-life business: The life business generates higher profitability in high GDP countries, low market concentration countries, low insurance penetration countries, low stock market turnover countries, ${ }^{15}$ low trade openness countries, high corruption (low corruption index) countries. The interaction effect of credit to private sector is unclear.

\section{Do the same strategies that improve performance also explain top performance?}

To examine whether the same business strategy choices that improve an insurer's performance also explain top performance, we classify each insurer as being a top performing insurer or not, and estimate logistic regression models explaining this classification. A logistic regression model simply allows us to statistically identify

\footnotetext{
${ }^{14} \mathrm{We}$ define each of these variables as done in Arena (2008). The specific definitions are as follows: GDP per capita: of ratio of total GDP to total population. GDP is in 2000 PPP-adjusted U.S.\$; Trade openness: Log of ratio of exports and imports (in 2000 U.S.\$) to GDP (in 2000 U.S.\$); Stock market turnover ratio: Ratio of the value of total shares traded and average real market capitalization; Insurance penetration: Insurance premium volume as a share of GDP; Inflation rate: Annual change in CPI; Credit to private sector: Private credit by deposit money banks to GDP.

${ }^{15}$ This result appears to support a substitution effect for life insurance. That is, if people cannot invest in capital markets they may buy more life insurance as an investment.
} 
Thomas R. Berry-Stölzle et al

Table 4 Interaction of business strategy variables with country characteristics

\begin{tabular}{|c|c|c|c|c|}
\hline \multirow{2}{*}{$\begin{array}{l}\text { Mediator variable: } \\
\text { Dependent variable: }\end{array}$} & \multicolumn{2}{|c|}{$G D P$ per capita } & \multicolumn{2}{|c|}{ Market concentration } \\
\hline & $R O E$ & $R A R O E$ & $R O E$ & $R A R O E$ \\
\hline \multicolumn{5}{|l|}{ Panel A } \\
\hline \multicolumn{5}{|l|}{ Interactions } \\
\hline $\begin{array}{l}\text { Diversification dummy*mediator-variable } \\
\text { (below 33rd percentile) }\end{array}$ & $\begin{array}{l}-0.026 \\
(-0.67)\end{array}$ & $\begin{array}{l}1.170 \\
(1.33)\end{array}$ & $\begin{array}{l}0.038 \\
(1.20)\end{array}$ & $\begin{array}{l}1.596^{* * *} \\
(1.99)\end{array}$ \\
\hline $\begin{array}{l}\text { Diversification dummy* mediator-variable } \\
\text { (between the 33rd and 66th percentile) }\end{array}$ & $\begin{array}{l}-0.028 \\
(-0.77)\end{array}$ & $\begin{array}{l}-0.061 \\
(-0.13)\end{array}$ & $\begin{array}{l}-0.019 \\
(-0.77)\end{array}$ & $\begin{array}{r}0.395 \\
(0.76)\end{array}$ \\
\hline $\begin{array}{l}\text { Diversification dummy* mediator-variable } \\
\text { (above the 66th percentile) }\end{array}$ & $\begin{array}{c}0.015 \\
(0.64)\end{array}$ & $\begin{array}{r}0.767 \\
(1.43)\end{array}$ & $\begin{array}{r}0.013 \\
(0.34)\end{array}$ & $\begin{array}{l}-0.224 \\
(-0.48)\end{array}$ \\
\hline $\begin{array}{l}\text { Fast growth dummy* mediator-variable } \\
\quad \text { (below } 33 \text { rd percentile) }\end{array}$ & $\begin{array}{r}0.025 \\
(1.02)\end{array}$ & $\begin{array}{r}0.860 \\
(1.28)\end{array}$ & $\begin{array}{l}0.047 * * \\
(2.38)\end{array}$ & $\begin{array}{r}0.177 \\
(0.61)\end{array}$ \\
\hline $\begin{array}{l}\text { Fast growth dummy* mediator-variable } \\
\text { (between the 33rd and 66th percentile) }\end{array}$ & $\begin{array}{l}0.038^{*} \\
(1.80)\end{array}$ & $\begin{array}{c}0.495 \\
(1.29)\end{array}$ & $\begin{array}{l}0.040^{* * *} \\
(2.23)\end{array}$ & $\begin{array}{l}0.723^{* * * *} \\
(2.67)\end{array}$ \\
\hline $\begin{array}{l}\text { Fast Growth Dummy* mediator-variable } \\
\text { (above the 66th percentile) }\end{array}$ & $\begin{array}{l}0.042^{* * *} \\
(2.35)\end{array}$ & $\begin{array}{r}0.203 \\
(1.19)\end{array}$ & $\begin{array}{l}0.048^{*} \\
(1.80)\end{array}$ & $\begin{array}{l}0.946^{* * * *} \\
(2.76)\end{array}$ \\
\hline $\begin{array}{l}\text { Slow growth dummy* mediator-variable } \\
\quad \text { (below } 33 \text { rd percentile) }\end{array}$ & $\begin{array}{l}-0.022 \\
(-0.62)\end{array}$ & $\begin{array}{l}-0.150 \\
(-0.34)\end{array}$ & $\begin{array}{l}-0.015 \\
(-0.59)\end{array}$ & $\begin{array}{l}-0.268 \\
(-1.26)\end{array}$ \\
\hline $\begin{array}{l}\text { Slow growth dummy* mediator-variable } \\
\text { (between the } 33 \text { rd and } 66 \text { th percentile) }\end{array}$ & $\begin{array}{l}-0.017 \\
(-0.73)\end{array}$ & $\begin{array}{l}-0.057 \\
(-0.18)\end{array}$ & $\begin{array}{l}-0.019 \\
(-0.89)\end{array}$ & $\begin{array}{c}0.199 \\
(0.84)\end{array}$ \\
\hline $\begin{array}{l}\text { Slow growth dummy* mediator-variable } \\
\text { (above the 66th percentile) }\end{array}$ & $\begin{array}{l}-0.011 \\
(-0.57)\end{array}$ & $\begin{array}{l}-0.058 \\
(-0.28)\end{array}$ & $\begin{array}{c}0.003 \\
(0.12)\end{array}$ & $\begin{array}{r}0.043 \\
(0.12)\end{array}$ \\
\hline $\begin{array}{l}\text { Life premium/premium* mediator-variable } \\
\text { (below 33rd percentile) }\end{array}$ & $\begin{array}{r}0.001 \\
(0.03)\end{array}$ & $\begin{array}{l}-0.075 \\
(-0.16)\end{array}$ & $\begin{array}{l}0.154^{* * * *} \\
(5.47)\end{array}$ & $\begin{array}{l}0.954^{* * * *} \\
(3.16)\end{array}$ \\
\hline $\begin{array}{l}\text { Life premium/premium* mediator-variable } \\
\text { (between the 33rd and 66th percentile) }\end{array}$ & $\begin{array}{l}0.073^{*} \\
(1.73)\end{array}$ & $\begin{array}{c}0.453 \\
(1.04)\end{array}$ & $\begin{array}{r}0.029 \\
(1.07)\end{array}$ & $\begin{array}{l}0.156 \\
(0.58)\end{array}$ \\
\hline $\begin{array}{l}\text { Life Premium/premium* mediator-variable } \\
\text { (above the } 66 \text { th percentile) }\end{array}$ & $\begin{array}{l}0.085^{* * *} \\
(3.62)\end{array}$ & $\begin{array}{l}0.600^{* *} \\
(2.37)\end{array}$ & $\begin{array}{r}0.036 \\
(0.89)\end{array}$ & $\begin{array}{r}0.432 \\
(0.81)\end{array}$ \\
\hline \multicolumn{5}{|l|}{ Control variables } \\
\hline $\ln$ (Total assets) & $\begin{array}{l}0.024 * * * \\
(3.17)\end{array}$ & $\begin{array}{l}0.316^{* * *} \\
(5.06)\end{array}$ & $\begin{array}{l}0.027 * * * \\
(3.51)\end{array}$ & $\begin{array}{l}0.344 * * * \\
(5.76)\end{array}$ \\
\hline Surplus/assets & $\begin{array}{r}0.079 \\
(1.30)\end{array}$ & $\begin{array}{l}1.452^{* * *} \\
(2.97)\end{array}$ & $\begin{array}{r}0.075 \\
(1.13)\end{array}$ & $\begin{array}{l}1.689^{* * * *} \\
(3.33)\end{array}$ \\
\hline Growth in assets & $\begin{array}{l}-0.003 \\
(-0.83)\end{array}$ & $\begin{array}{l}-0.026 \\
(-1.25)\end{array}$ & $\begin{array}{l}-0.003 \\
(-0.80)\end{array}$ & $\begin{array}{c}-0.027 \\
(-1.31)\end{array}$ \\
\hline Growth in income & $\begin{array}{c}0.000 \\
(1.27)\end{array}$ & $\begin{array}{c}0.000 \\
(0.60)\end{array}$ & $\begin{array}{l}0.000 * * \\
(2.01)\end{array}$ & $\begin{array}{r}0.000 \\
(0.79)\end{array}$ \\
\hline Mutual dummy & $\begin{array}{l}-0.008 \\
(-0.09)\end{array}$ & $\begin{array}{l}2.029 * * \\
(2.12)\end{array}$ & $\begin{array}{c}0.010 \\
(0.12)\end{array}$ & $\begin{array}{l}2.136^{* *} \\
(2.21)\end{array}$ \\
\hline Group dummy & $\begin{array}{c}0.001 \\
(0.07)\end{array}$ & $\begin{array}{r}0.057 \\
(0.23)\end{array}$ & $\begin{array}{l}-0.007 \\
(-0.32)\end{array}$ & $\begin{array}{r}0.029 \\
(0.11)\end{array}$ \\
\hline GDP per capita growth & $\begin{array}{l}0.816^{*} \\
(1.82)\end{array}$ & $\begin{array}{c}9.576 \\
(1.31)\end{array}$ & $\begin{array}{l}-0.128 \\
(-0.25)\end{array}$ & $\begin{array}{l}-0.100 \\
(-0.01)\end{array}$ \\
\hline Inflation & $\begin{array}{l}0.004^{*} \\
(1.68)\end{array}$ & $\begin{array}{l}-0.014 \\
(-0.40)\end{array}$ & $\begin{array}{l}-0.001 \\
(-0.35)\end{array}$ & $\begin{array}{l}-0.050 \\
(-0.93)\end{array}$ \\
\hline$R^{2}$ & 0.203 & 0.253 & 0.203 & 0.238 \\
\hline No. of observations & 1501 & 1501 & 1371 & 1371 \\
\hline
\end{tabular}


Table 4 (continued)

\begin{tabular}{|c|c|c|c|c|}
\hline \multirow{2}{*}{$\begin{array}{l}\text { Mediator variable: } \\
\text { Dependent variable: }\end{array}$} & \multicolumn{2}{|c|}{ Insurance penetration } & \multicolumn{2}{|c|}{ Credit to private sector } \\
\hline & $R O E$ & $R A R O E$ & $R O E$ & $R A R O E$ \\
\hline \multicolumn{5}{|l|}{ Panel B } \\
\hline \multicolumn{5}{|l|}{ Interactions } \\
\hline \multirow{2}{*}{$\begin{array}{l}\text { Diversification dummy*mediator-variable } \\
\text { (below 33rd percentile) }\end{array}$} & 0.032 & 0.337 & 0.012 & 0.196 \\
\hline & $(1.17)$ & $(1.20)$ & $(0.48)$ & $(0.66)$ \\
\hline \multirow{2}{*}{$\begin{array}{l}\text { Diversification dummy* mediator-variable } \\
\text { (between the 33rd and 66th percentile) }\end{array}$} & -0.016 & 0.701 & 0.024 & $1.747^{* *}$ \\
\hline & $(-0.50)$ & $(1.05)$ & $(0.70)$ & $(2.00)$ \\
\hline \multirow{2}{*}{$\begin{array}{l}\text { Diversification dummy* mediator-variable } \\
\text { (above the 66th percentile) }\end{array}$} & -0.018 & 0.651 & $-0.049 *$ & 0.130 \\
\hline & $(-0.55)$ & $(0.88)$ & $(-1.75)$ & $(0.19)$ \\
\hline \multirow{2}{*}{$\begin{array}{l}\text { Fast growth dummy* mediator-variable } \\
\quad \text { (below 33rd percentile) }\end{array}$} & $0.043 * *$ & 0.312 & $0.039 *$ & 0.065 \\
\hline & $(2.08)$ & $(1.60)$ & $(1.95)$ & $(0.31)$ \\
\hline \multirow{2}{*}{$\begin{array}{l}\text { Fast growth dummy* mediator-variable } \\
\text { (between the } 33 \mathrm{rd} \text { and } 66 \text { th percentile) }\end{array}$} & $0.036^{*}$ & 0.467 & $0.042 * *$ & $0.753 *$ \\
\hline & $(1.89)$ & $(1.24)$ & $(1.99)$ & $(1.88)$ \\
\hline \multirow{2}{*}{$\begin{array}{l}\text { Fast Growth Dummy* mediator-variable } \\
\text { (above the 66th percentile) }\end{array}$} & 0.031 & 0.597 & $0.035^{* *}$ & 0.569 \\
\hline & $(1.48)$ & $(1.38)$ & $(1.98)$ & $(1.37)$ \\
\hline \multirow{2}{*}{$\begin{array}{l}\text { Slow growth dummy* mediator-variable } \\
\text { (below 33rd percentile) }\end{array}$} & -0.011 & -0.118 & -0.010 & $-0.325^{*}$ \\
\hline & $(-0.42)$ & $(-0.73)$ & $(-0.42)$ & $(-1.78)$ \\
\hline \multirow{2}{*}{$\begin{array}{l}\text { Slow growth dummy* mediator-variable } \\
\text { (between the } 33 \text { rd and 66th percentile) }\end{array}$} & -0.027 & -0.581 & 0.028 & $0.631 *$ \\
\hline & $(-1.23)$ & $(-1.61)$ & $(1.18)$ & $(1.77)$ \\
\hline \multirow{2}{*}{$\begin{array}{l}\text { Slow growth dummy* mediator-variable } \\
\text { (above the 66th percentile) }\end{array}$} & -0.005 & 0.541 & $-0.052 * *$ & -0.086 \\
\hline & $(-0.24)$ & $(1.25)$ & $(-2.28)$ & $(-0.22)$ \\
\hline \multirow{2}{*}{$\begin{array}{l}\text { Life premium/premium* mediator-variable } \\
\text { (below } 33 \text { rd percentile) }\end{array}$} & $0.125^{* * *}$ & $0.604 * * *$ & $0.122 * * *$ & $0.653^{* * *}$ \\
\hline & $(4.60)$ & $(2.87)$ & $(4.43)$ & $(3.03)$ \\
\hline \multirow{2}{*}{$\begin{array}{l}\text { Life premium/premium* mediator-variable } \\
\text { (between the } 33 \text { rd and 66th percentile) }\end{array}$} & 0.036 & 0.740 & 0.014 & 0.478 \\
\hline & $(0.98)$ & $(1.51)$ & $(0.34)$ & $(0.91)$ \\
\hline \multirow{2}{*}{$\begin{array}{l}\text { Life Premium/premium* mediator-variable } \\
\text { (above the 66th percentile) }\end{array}$} & 0.010 & -0.163 & $0.057 *$ & 0.228 \\
\hline & $(0.29)$ & $(-0.34)$ & $(1.67)$ & $(0.50)$ \\
\hline \multicolumn{5}{|l|}{ Control variables } \\
\hline \multirow[t]{2}{*}{$\ln$ (Total assets) } & $0.027 * * *$ & $0.328 * * *$ & $0.025 * * *$ & $0.308 * * *$ \\
\hline & $(3.41)$ & $(5.21)$ & $(3.23)$ & $(5.01)$ \\
\hline \multirow[t]{2}{*}{ Surplus/assets } & 0.069 & $1.570 * * *$ & 0.059 & $1.445^{* * *}$ \\
\hline & $(1.10)$ & $(3.05)$ & $(0.99)$ & $(2.98)$ \\
\hline \multirow[t]{2}{*}{ Growth in assets } & -0.003 & -0.027 & -0.003 & $-0.033^{*}$ \\
\hline & $(-0.86)$ & $(-1.34)$ & $(-0.95)$ & $(-1.84)$ \\
\hline \multirow[t]{2}{*}{ Growth in income } & 0.000 & 0.000 & 0.000 & 0.000 \\
\hline & $(0.80)$ & $(0.27)$ & $(0.79)$ & $(0.22)$ \\
\hline \multirow[t]{2}{*}{ Mutual dummy } & 0.017 & $2.089 * *$ & 0.016 & $2.111 * *$ \\
\hline & $(0.19)$ & $(2.14)$ & $(0.18)$ & $(2.09)$ \\
\hline Group dummy & -0.004 & 0.062 & 0.000 & 0.028 \\
\hline & $(-0.20)$ & $(0.25)$ & $(0.02)$ & $(0.11)$ \\
\hline GDP per capita growth & 0.703 & 6.742 & $0.754^{*}$ & 8.901 \\
\hline & $(1.54)$ & $(0.95)$ & $(1.65)$ & $(1.23)$ \\
\hline Inflation & 0.003 & -0.017 & 0.004 & -0.003 \\
\hline & $(1.50)$ & $(-0.50)$ & $(1.56)$ & $(-0.09)$ \\
\hline$R^{2}$ & 0.201 & 0.248 & 0.213 & 0.261 \\
\hline No. of observations & 1453 & 1453 & 1501 & 1501 \\
\hline
\end{tabular}


Thomas R. Berry-Stölzle et al

Table 4 (continued)

\begin{tabular}{|c|c|c|c|c|}
\hline \multirow{2}{*}{$\begin{array}{l}\text { Mediator variable: } \\
\text { Dependent variable: }\end{array}$} & \multicolumn{2}{|c|}{ Stock market turnover } & \multicolumn{2}{|c|}{ Trade openness } \\
\hline & ROE & $R A R O E$ & $R O E$ & $R A R O E$ \\
\hline \multicolumn{5}{|l|}{ Panel C } \\
\hline \multicolumn{5}{|l|}{ Interactions } \\
\hline $\begin{array}{l}\text { Diversification dummy*mediator-variable } \\
\text { (below 33rd percentile) }\end{array}$ & $\begin{array}{l}-0.014 \\
(-0.46)\end{array}$ & $\begin{array}{r}0.039 \\
(0.10)\end{array}$ & $\begin{array}{r}0.031 \\
(0.79)\end{array}$ & $\begin{array}{l}0.904^{* *} \\
(2.21)\end{array}$ \\
\hline $\begin{array}{l}\text { Diversification dummy* mediator-variable } \\
\text { (between the 33rd and 66th percentile) }\end{array}$ & $\begin{array}{l}-0.019 \\
(-0.77)\end{array}$ & $\begin{array}{r}0.430 \\
(0.77)\end{array}$ & $\begin{array}{l}-0.020 \\
(-0.76)\end{array}$ & $\begin{array}{l}1.535^{*} \\
(1.86)\end{array}$ \\
\hline $\begin{array}{l}\text { Diversification dummy* mediator-variable } \\
\text { (above the 66th percentile) }\end{array}$ & $\begin{array}{c}0.031 \\
(0.80)\end{array}$ & $\begin{array}{r}1.089 \\
(1.57)\end{array}$ & $\begin{array}{c}0.002 \\
(0.06)\end{array}$ & $\begin{array}{l}-1.166^{* *} \\
(-2.21)\end{array}$ \\
\hline $\begin{array}{l}\text { Fast growth dummy* mediator-variable } \\
\quad \text { (below 33rd percentile) }\end{array}$ & $\begin{array}{r}0.027 \\
(1.31)\end{array}$ & $\begin{array}{r}0.223 \\
(0.83)\end{array}$ & $\begin{array}{l}0.035^{* *} \\
(2.12)\end{array}$ & $\begin{array}{l}0.550^{* * *} \\
(2.72)\end{array}$ \\
\hline $\begin{array}{l}\text { Fast growth dummy* mediator-variable } \\
\quad \text { (between the } 33 \text { rd and 66th percentile) }\end{array}$ & $\begin{array}{l}0.054^{* * * *} \\
(3.21)\end{array}$ & $\begin{array}{l}0.556^{* * *} \\
(2.17)\end{array}$ & $\begin{array}{l}0.068^{* * * *} \\
(3.09)\end{array}$ & $\begin{array}{r}0.255 \\
(0.55)\end{array}$ \\
\hline $\begin{array}{l}\text { Fast growth dummy* mediator-variable } \\
\text { (above the 66th percentile) }\end{array}$ & $\begin{array}{r}0.018 \\
(0.81)\end{array}$ & $\begin{array}{r}0.304 \\
(0.64)\end{array}$ & $\begin{array}{r}0.023 \\
(0.87)\end{array}$ & $\begin{array}{r}0.440 \\
(0.87)\end{array}$ \\
\hline $\begin{array}{l}\text { Slow growth dummy* mediator-variable } \\
\quad \text { (below } 33 \text { rd percentile) }\end{array}$ & $\begin{array}{l}-0.012 \\
(-0.39)\end{array}$ & $\begin{array}{r}0.051 \\
(0.21)\end{array}$ & $\begin{array}{l}-0.027 \\
(-1.32)\end{array}$ & $\begin{array}{r}0.059 \\
(0.35)\end{array}$ \\
\hline $\begin{array}{l}\text { Slow growth dummy* mediator-variable } \\
\text { (between the } 33 \mathrm{rd} \text { and } 66 \text { th percentile) }\end{array}$ & $\begin{array}{l}-0.012 \\
(-0.68)\end{array}$ & $\begin{array}{l}-0.080 \\
(-0.35)\end{array}$ & $\begin{array}{r}0.015 \\
(0.60)\end{array}$ & $\begin{array}{l}-0.367 \\
(-0.74)\end{array}$ \\
\hline $\begin{array}{l}\text { Slow growth dummy* mediator-variable } \\
\text { (above the 66th percentile) }\end{array}$ & $\begin{array}{l}-0.017 \\
(-0.59)\end{array}$ & $\begin{array}{l}-0.045 \\
(-0.12)\end{array}$ & $\begin{array}{l}-0.042^{*} \\
(-1.70)\end{array}$ & $\begin{array}{l}-0.269 \\
(-0.64)\end{array}$ \\
\hline $\begin{array}{l}\text { Life premium/premium* mediator-variable } \\
\text { (below 33rd percentile) }\end{array}$ & $\begin{array}{l}0.129 * * * \\
(4.43)\end{array}$ & $\begin{array}{r}0.455 \\
(1.54)\end{array}$ & $\begin{array}{l}0.083^{* * * *} \\
(3.14)\end{array}$ & $\begin{array}{l}0.589 * * * \\
(2.79)\end{array}$ \\
\hline $\begin{array}{l}\text { Life premium/premium* mediator-variable } \\
\text { (between the } 33 \text { rd and 66th percentile) }\end{array}$ & $\begin{array}{l}0.058 * * \\
(2.52)\end{array}$ & $\begin{array}{r}0.428 \\
(1.62)\end{array}$ & $\begin{array}{l}0.073^{* *} \\
(2.34)\end{array}$ & $\begin{array}{r}0.709 \\
(1.28)\end{array}$ \\
\hline $\begin{array}{l}\text { Life premium/premium* mediator-variable } \\
\text { (above the } 66 \text { th percentile) }\end{array}$ & $\begin{array}{r}0.046 \\
(1.11)\end{array}$ & $\begin{array}{r}0.619 \\
(1.30)\end{array}$ & $\begin{array}{r}0.012 \\
(0.26)\end{array}$ & $\begin{array}{r}0.175 \\
(0.26)\end{array}$ \\
\hline Control variables & & & & \\
\hline ln (Total assets) & $\begin{array}{l}0.024 * * * \\
(3.19)\end{array}$ & $\begin{array}{l}0.300^{* * *} \\
(5.13)\end{array}$ & $\begin{array}{l}0.021 * * * \\
(2.68)\end{array}$ & $\begin{array}{l}0.303^{* * * *} \\
(4.80)\end{array}$ \\
\hline Surplus/assets & $\begin{array}{c}0.066 \\
(1.08)\end{array}$ & $\begin{array}{l}1.511 * * * \\
(3.07)\end{array}$ & $\begin{array}{c}0.052 \\
(0.85)\end{array}$ & $\begin{array}{l}1.226^{* *} \\
(2.38)\end{array}$ \\
\hline Growth in assets & $\begin{array}{c}-0.003 \\
(-0.88)\end{array}$ & $\begin{array}{l}-0.025 \\
(-1.23)\end{array}$ & $\begin{array}{l}-0.003 \\
(-0.90)\end{array}$ & $\begin{array}{l}-0.028 \\
(-1.55)\end{array}$ \\
\hline Growth in income & $\begin{array}{c}0.000 \\
(1.56)\end{array}$ & $\begin{array}{c}0.000 \\
(0.46)\end{array}$ & $\begin{array}{c}0.000 \\
(1.53)\end{array}$ & $\begin{array}{c}0.000 \\
(0.47)\end{array}$ \\
\hline Mutual dummy & $\begin{array}{r}0.001 \\
(0.01)\end{array}$ & $\begin{array}{l}2.033^{* *} \\
(2.07)\end{array}$ & $\begin{array}{c}0.031 \\
(0.33)\end{array}$ & $\begin{array}{l}2.446^{* * *} \\
(2.48)\end{array}$ \\
\hline Group dummy & $\begin{array}{l}-0.001 \\
(-0.04)\end{array}$ & $\begin{array}{c}0.059 \\
(0.23)\end{array}$ & $\begin{array}{l}-0.004 \\
(-0.20)\end{array}$ & $\begin{array}{r}0.043 \\
(0.17)\end{array}$ \\
\hline GDP per capita growth & $\begin{array}{c}0.800 \\
(1.60)\end{array}$ & $\begin{array}{c}11.148 \\
(1.30)\end{array}$ & $\begin{array}{c}0.719 \\
(1.39)\end{array}$ & $\begin{array}{c}4.564 \\
(0.60)\end{array}$ \\
\hline Inflation & $\begin{array}{r}0.003 \\
(0.89)\end{array}$ & $\begin{array}{c}-0.028 \\
(-0.63)\end{array}$ & $\begin{array}{c}0.004 \\
(1.04)\end{array}$ & $\begin{array}{l}-0.055 \\
(-1.09)\end{array}$ \\
\hline$R^{2}$ & 0.199 & 0.247 & 0.213 & 0.258 \\
\hline No. of observations & 1477 & 1477 & 1341 & 1341 \\
\hline
\end{tabular}


Table 4 (continued)

Mediator variable:

Corruption index

Dependent variable:

$R O E$

RAROE

Panel D

Interactions

Diversification dummy*mediator-variable (below 33rd percentile)

Diversification dummy* mediator-variable (between the 33rd and 66th percentile)

Diversification dummy* mediator-variable (above the 66th percentile)

Fast growth dummy* mediator-variable (below 33rd percentile)

Fast growth dummy* mediator-variable (between the 33rd and 66th percentile)

Fast growth dummy* mediator-variable (above the 66th percentile)

Slow growth dummy* mediator-variable (below 33rd percentile)

Slow growth dummy* mediator-variable (between the 33rd and 66th percentile)

Slow growth dummy* mediator-variable (above the 66th percentile)

Life premium/premium* mediator-variable (below 33rd percentile)

Life premium/premium* mediator-variable (between the 33rd and 66th percentile)

Life premium/premium* mediator-variable (above the 66th percentile)

$\begin{array}{cc}0.031 & 1.144^{* *} \\ (1.21) & (2.14) \\ 0.011 & 1.214^{* *} \\ (0.37) & (2.06) \\ -0.034 & -0.272 \\ (-1.24) & (-0.48) \\ 0.025 & 0.348 \\ (1.18) & (1.29) \\ 0.065^{* * * *} & 0.309 \\ (3.24) & (0.87) \\ 0.032 & 0.508 \\ (1.63) & (1.37) \\ -0.027 & -0.131 \\ (-1.10) & (-0.72) \\ 0.043 & -0.212 \\ (1.58) & (-0.59) \\ -0.045^{* *} & 0.187 \\ (-2.14) & (0.52) \\ 0.103^{* * *} & 0.517^{* *} \\ (3.28) & (2.34) \\ 0.081^{* *} & 0.787 \\ (2.02) & (1.59) \\ 0.040 & 0.369 \\ (1.24) & (0.90)\end{array}$

Control variables

$\ln$ (Total assets)

$0.025^{* * *}$

$0.286^{* * *}$

(3.38)

(4.58)

Surplus/assets

0.067

$1.386^{* * * *}$

(1.10)

(2.77)

Growth in assets

$-0.003$

$-0.032$

Growth in income

$(-0.97)$

0.000

$(-1.63)$

0.000

(1.20)

$(0.62)$

Mutual dummy

0.006

$2.128 * *$

(0.06)

(2.06)

Group dummy

$-0.001$

0.009

$(-0.06)$

(0.04)

GDP per capita growth

$0.904 * *$

11.957

(2.02)

(1.54)

Inflation

0.003

$-0.026$

(1.19)

$(-0.69)$

0.210

0.257

No. of observations

1501

Note: The regressions include country and year dummies (not reported). Standard errors are adjusted for clustering at the company level. Data are for the years 2004 through 2007. ***,**, and * denotes statistical significance at the 1,5 , and 10 per cent level, respectively. 
characteristics that are related to whether an insurer falls into one category or another. In this case, whether it is a top-performing insurer or not. The Top 10 per cent Insurers (Top 20 per cent Insurers) dummy variable is coded as 1 if a insurer is above the $90^{\text {th }}$ percentile $\left(80^{\text {th }}\right.$ percentile) value of the distribution of ROE across our sample for a given year. We code the same dummies for the RAROE performance measure as well. The logistic regressions include the same variables describing insurer and country characteristics used in our standard regression models; again, we control for year- and country-fixed effects. The results of this analysis are presented in Table 5.

The results suggest that Fast Growth is consistently positive and significant; diversification is only significant for top 10 per cent RAROE insurers (the impact is positive); life insurance business is more profitable; surplus to assets ratio is negative and significant for ROE and positive and significant for RAROE. This highlights the importance of considering risk when judging the impact of financial leverage on performance.

\section{Conclusion}

Entering new markets and growing in existing ones is an area of major interest within the insurance industry across the globe. Insurance market growth rates in emerging markets are far in excess of those available in most developed countries. In our sample of over 450 insurers from over 50 countries the median ROE is 13.49 per cent and the median one year premium growth rate is 24.58 per cent, documenting fast growth and solid earnings for insurers operating in emerging markets over the period 2004-2007. While these growth rates have attracted new and existing firms to these markets, corporate managers face a number of important strategic decisions as they consider establishing or expanding operations in emerging markets.

Our results suggest that overall, successful business strategies for emerging markets involve a high growth rate, increased size and more emphasis on life insurance. When performance is adjusted for risk, lower financial leverage and mutual organisational form are also associated with better performance. Our analysis further evaluates which country-specific characteristics contribute to better performance by insurers adopting the three core strategies of diversification, growth and emphasis on life insurance. A diversification strategy leads to better performance in countries with higher corruption ratings, lower market competition and lower trade openness. A growth strategy is associated with better performance when per capita GDP is higher, when insurance penetration is lower, and when trade openness is lower. A business focus on life insurance leads to better performance in countries with higher GDP, strong market competition, lower insurance penetration, lower stock market turnover, lower trade openness and higher corruption ratings. Finally, reinforcing our other results, topperforming insurers in our sample focused more on life insurance, were larger and had faster premium growth. When performance was adjusted for risk, they also tended to be mutuals.

Obviously, in the increasingly global marketplace insurers must assess the opportunities to enter new markets and to grow in existing ones. As our data confirm, insurance market growth rates in emerging markets are far in excess of those available in most developed countries. However, as we have also demonstrated in 
Table 5 Logistic regression of top-performance dummy on strategy variables and controls

\begin{tabular}{|c|c|c|c|c|}
\hline & \multicolumn{2}{|c|}{$R O E$} & \multicolumn{2}{|c|}{$R A R O E$} \\
\hline & Top $20 \%$ insurers & Top $10 \%$ insurers & Top 20\% insurers & Top $10 \%$ insurers \\
\hline \multirow[t]{2}{*}{ Diversification dummy } & -0.267 & -0.492 & 0.100 & $0.586^{*}$ \\
\hline & $(-1.18)$ & $(-1.57)$ & $(0.42)$ & $(1.95)$ \\
\hline \multirow[t]{2}{*}{ Fast growth dummy } & $0.384 * *$ & $0.535^{* *}$ & $0.566^{* * *}$ & $0.617^{* *}$ \\
\hline & $(2.26)$ & $(2.30)$ & $(3.04)$ & $(2.52)$ \\
\hline \multirow[t]{2}{*}{ Slow growth dummy } & -0.103 & 0.062 & 0.243 & 0.234 \\
\hline & $(-0.55)$ & $(0.25)$ & $(1.22)$ & $(0.87)$ \\
\hline \multirow[t]{2}{*}{ Life premium/premium } & $0.799 * * *$ & $1.328 * * *$ & -0.073 & $0.514^{*}$ \\
\hline & $(4.67)$ & $(5.62)$ & $(-0.33)$ & $(1.78)$ \\
\hline \multirow[t]{2}{*}{ ln (Total assets) } & $0.102^{* *}$ & $0.135^{*}$ & $0.294 * * *$ & 0.116 \\
\hline & $(1.97)$ & $(1.91)$ & $(5.20)$ & $(1.60)$ \\
\hline \multirow[t]{2}{*}{ Surplus/assets } & $-0.917^{*}$ & $-1.297^{*}$ & $0.961^{*}$ & 0.416 \\
\hline & $(-1.92)$ & $(-1.92)$ & $(1.79)$ & $(0.57)$ \\
\hline \multirow[t]{2}{*}{ Growth in assets } & 0.026 & -0.013 & -0.006 & 0.011 \\
\hline & (1.49) & $(-0.53)$ & $(-0.29)$ & $(0.62)$ \\
\hline \multirow[t]{2}{*}{ Growth in income } & -0.000 & -0.003 & 0.000 & -0.001 \\
\hline & $(-0.27)$ & $(-0.99)$ & $(0.14)$ & $(-0.18)$ \\
\hline \multirow[t]{2}{*}{ Mutual dummy } & -0.141 & 0.773 & $2.435^{* * *}$ & $2.233^{* * *}$ \\
\hline & $(-0.26)$ & $(1.20)$ & $(5.66)$ & $(3.77)$ \\
\hline \multirow[t]{2}{*}{ Group dummy } & 0.134 & $0.413^{*}$ & 0.137 & -0.217 \\
\hline & $(0.76)$ & $(1.75)$ & $(0.73)$ & $(-0.86)$ \\
\hline \multirow[t]{2}{*}{ GDP per capita growth } & 4.643 & 11.688 & $-15.541 *$ & -3.351 \\
\hline & $(0.58)$ & $(0.86)$ & $(-1.73)$ & $(-0.28)$ \\
\hline \multirow[t]{2}{*}{ Inflation } & 0.038 & -0.006 & -0.002 & -0.003 \\
\hline & $(1.05)$ & $(-0.10)$ & $(-0.04)$ & $(-0.05)$ \\
\hline$R^{2}$ & 0.169 & 0.257 & 0.244 & 0.259 \\
\hline$\chi^{2}$ & 258.08 & 259.46 & 354.63 & 237.80 \\
\hline No. of observations & 1501 & 1501 & 1501 & 1501 \\
\hline
\end{tabular}

Note: The regressions include country and year dummies (not reported). Data are for the years 2004 through 2007 . $* * * * *$, and $*$ denotes statistical significance at the 1,5 , and 10 per cent level, respectively.

this study, important differences exist across developing countries in terms of successful business strategies. A number of factors will affect whether an insurer operating in emerging markets will achieve top performance or disappointment. Nevertheless, the results of this study give corporate managers some sense for what those successful business strategies might be.

\section{References}

Arena, M. (2008) 'Does insurance market activity promote economic growth? A cross-country study for industrialized and developing countries', Journal of Risk and Insurance 75(4): 921-946.

Berger, A.N., Cummins, J.D., Weiss, M.A. and Zi, H. (2000) 'Conglomeration versus strategic focus: Evidence from the insurance industry', Journal of Financial Intermediation 9: 323-362.

Berger, P.G. and Ofek, E. (1995) 'Diversification's effect on firm value', Journal of Financial Economics 37: 39-65.

Browne, M.J. and Kim, K. (1993) 'An international analysis of life insurance demand', Journal of Risk and Insurance 60(4): 671-688. 
Browne, M.J., Chung, J. and Frees, E.W. (2000) 'International property-liability insurance consumption', Journal of Risk and Insurance 67(1): 391-410.

Colquitt, L.L. and Hoyt, R.E. (1997) 'Determinants of corporate hedging behavior: Evidence from the life insurance industry', Journal of Risk and Insurance 64: 649-671.

Comment, R. and Jarrell, G.A. (1995) 'Corporate focus and stock returns', Journal of Financial Economics 37: $67-87$.

Cummins, J.D., Weiss, M.A. and Zi, H. (2003) Economies of Scope in Financial Services: $A$ DEA Bootstrapping Analysis of the U.S. Insurance Industry, working paper, Wharton Financial Institutions Center, Philadelphia, PA.

Denis, J.D., Denis, D.K. and Sarin, A. (1997) 'Agency problems, equity ownership, and corporate diversification', Journal of Finance 52: 135-160.

Graham, J. and Rogers, D. (2002) 'Do firms hedge in response to tax incentives?' Journal of Finance 57: 815-839.

Hoyt, R.E. and Trieschmann, J.S. (1991) 'Risk/return relationship for life-health, property-liability, and diversified insurers', Journal of Risk and Insurance 58: 322-330.

Hubbard, R.G. and Palia, D. (1999) 'A reexamination of the conglomerate merger wave in the 1960s: An internal capital markets view', Journal of Finance 54: 1131-1152.

Hussels, S., Ward, D. and Zurbruegg, R. (2005) 'Stimulating the demand for insurance', Risk Management and Insurance Review 8(2): 257-278.

John, K. and Ofek, E. (1995) 'Asset sales and increase in focus', Journal of Financial Economics 37: $105-126$.

Laeven, L. and Levine, R. (2007) 'Is there a diversification discount in financial conglomerates?' Journal of Financial Economics 85: 331-367.

Lang, L.H.P. and Stulz, R.M. (1994) 'Tobin's q, corporate diversification, and firm performance', Journal of Political Economy 102(6): 1248-1280.

Lawellen, W.G. (1971) 'A pure financial rationale for the conglomerate merger', Journal of Finance 26: 521-537.

Leland, H.E. (1998) 'Agency costs, risk management, and capital structure', Journal of Finance 53: 1213-1243.

Liebenberg, A.P. and Sommer, D.W. (2008) 'Effects of corporate diversification: Evidence from the property-liability insurance industry', Journal of Risk and Insurance 75: 893-919.

Ma, Y.L. and Pope, N. (2008) 'The market structure-performance relationship in the international insurance sector', Journal of Risk and Insurance 75(4): 947-966.

Markides, C.C. (1992) 'Consequences of corporate refocusing: Ex ante evidence', Academy of Management Journal 35: 398-412.

Matsusaka, J.G. (1993) 'Takeover motives during the conglomerate merger wave', RAND Journal of Economics 24: 357-379.

Myers, S.C. and Majluf, N.S. (1984) 'Corporate financing and investment decisions when firms have information that investors do not have', Journal of Financial Economics 13: 187-221.

Outreville, J.F. (1990) 'The Economic Significance of Insurance Markets in Developing Countries', Journal of Risk and Insurance 57(3): 487-498.

Outreville, J.F. (1996) 'Life Insurance Markets in Developing Countries', Journal of Risk and Insurance 63(2): 263-278.

Servaes, H. (1996) 'The value of diversification during the conglomerate merger wave', Journal of Finance 51: 1201-1225.

Stulz, R.M. (1996) 'Rethinking risk management', Journal of Applied Corporate Finance 9: 8-24.

Teece, D.J. (1980) 'Economies of scope and the scope of the enterprise', Journal of Economic Behavior and Organization 1: 223-247.

Tombs, J.W. and Hoyt, R.E. (1994) 'The Effect of Product Line Focus on Insurer Stock Returns', in Proceedings of the International Insurance Association Annual Meeting, Madrid, Spain, pp. 331-337.

Ward, D. and Zurbruegg, R. (2000) 'Does Insurance Promote Economic Growth? Evidence From OECD Countries', Journal of Risk and Insurance 67(4): 489-506.

Webb, I., Grace, M.F. and Skipper, H.D. (2002) The Effect of Banking and Insurance on the Growth of Capital and Output, Working paper 02-1, Center for Risk Management and Insurance, Robinson College of Business, Georgia State University, Atlanta, GA. 


\section{About the Authors}

Thomas R. Berry-Stölzle is an assistant professor of Risk Management and Insurance in the Terry College of Business at the University of Georgia. He has been on the UGA faculty since 2007 and teaches Corporate Risk Management, Insurance Markets, and Insurance Company Operations. Dr Berry-Stölzle holds a degree in Applied Mathematics with a concentration in actuarial science from Ulm University and a PhD degree in Risk Management and Insurance from the University of Cologne. His research interests are focused in the areas of enterprise risk management, insurance company operations, and the economics of insurance regulation.

Robert E. Hoyt is the Dudley L. Moore, Jr. chair of Risk Management and Insurance in the Terry College of Business at the University of Georgia. He teaches Corporate Risk Management and Enterprise Risk Management and serves as the department head for Insurance, Legal Studies, and Real Estate. He was Interim Dean of the Terry College in 2007 and has been on the UGA faculty since 1988. Dr Hoyt holds a degree in Actuarial Science from the University of Nebraska and MA and PhD degrees in Risk and Insurance from the Wharton School of the University of Pennsylvania where he was an S.S. Huebner Fellow. Dr Hoyt's research interests are focused in the areas of corporate hedging, enterprise risk management, catastrophe risk management, the economics of insurance fraud, liability system costs, and insurer insolvency.

Sabine Wende is a fourth year PhD student in the Department of Risk Management and Insurance at the University of Cologne. Wende received her Diploma in Business Administration from the University of Cologne in 2006. Her current areas of research are insurer operations and efficiency. 